\title{
Evaluation of injuries caused by anthropic action in snakes from Brazil
}

\author{
Gouveia, RV. ${ }^{a}$, Neto-Silva, DA. ${ }^{b}$, Sousa, BM. ${ }^{a}$ and Novelli, IA. ${ }^{a *}$ \\ aPrograma de Pós-graduação em Ciências Biológicas: Comportameto e Biologia Animal, Universidade Federal de Juiz de \\ Fora - UFJF, Campus Universitário, Rua José Lourenço Kelmer, s/n, São Pedro, CEP 36036-900, Juiz de Fora, MG, Brazil \\ bLaboratório de Zoologia, Centro Universitário de Lavras - UNILAVRAS, Rua Padre José Poggel, 506, Centenário, \\ CEP 37200-000, Lavras, MG, Brazil \\ *e-mail: iaranovelli27@gmail.com
}

Received: August 30, 2013 - Accepted: May 13, 2014 - Distributed: August 31, 2015

\begin{abstract}
Human behavior toward wild animals is defined by cultural influences and often is affected by lack of knowledge, mainly in situations of confrontation. The present study was conducted between 2008 and 2013, involving analysis of snakes that had suffered injuries belonging to the reptile collections of Centro Universitário de Lavras and Universidade Federal de Juiz de Fora. The injuries were classified according to location on the body. Among the 449 specimens analyzed, 245 specimens showed injury to some part of the body. The nonvenomous snakes were the most representative and had a higher rate of injury (66.3\%) than the venomous ones $(18.2 \%)$. The body region where the greatest percentage of injuries was recorded was the anterior (39.6\%), followed by the middle (36.5\%) and posterior $(8.4 \%)$. We believe this fact may have resulted due the lack of knowledge on how to differentiate species. Studies of the relationship between schooling level and contact with environmental education activities demonstrate reduction of attacks on these animals. This fact indicates that the preservation of many species is related to awareness and education of the population.
\end{abstract}

Keywords: conservation of natural resources, environmental education, injuries, snakes.

\section{Avaliação das lesões causadas pela ação antrópica em serpentes do Brasil}

\section{Resumo}

O comportamento humano para com os animais selvagens é definido por influências culturais e muitas vezes é afetado por falta de conhecimento, principalmente em situações de confronto. Podendo levar à matança indiscriminada, consequentemente a um estado de declínio. O presente estudo foi realizado entre 2008 e 2013, envolvendo a análise de serpente que sofreram lesões pertencentes às coleções de répteis do Centro Universitário de Lavras e Universidade Federal de Juiz de Fora. As lesões foram classificadas de acordo com a localização no corpo. Entre os 449 espécimes analisados, 245 mostram lesões. As serpentes não peçonhentas foram as mais representativas e apresentaram uma maior taxa de lesão $(66,3 \%)$ do que os peçonhentos $(18,2 \%)$. A região do corpo onde ocorreu a maior percentagem de lesões registada foi a anterior $(39,6 \%)$, seguido pelo meio $(36,5 \%)$ e posterior $(8,4 \%)$. Acreditamos que este fato pode ter resultado devido a falta de conhecimento sobre como diferenciar espécies. Estudos sobre a relação entre nível de escolaridade e contato com atividades de educação ambiental demonstram redução dos ataques a esses animais. Este fato indica que a preservação de muitas espécies está relacionado à conscientização e educação da população.

Palavras-chave: conservação de recursos naturais, educação ambiental, injúrias, serpentes.

\section{Introduction}

Snakes have always been objects of both great curiosity and fear among humans. Because human behavior toward animals is influenced by cultural perceptions and since there is often a lack of knowledge about animals and their behavior and role in the food chain and ecosystem, as well as about how to act during confrontations, certain species face indiscriminate extermination. In extreme cases this can lead species to a state of decline (Wilson, 1984; Pough et al., 2001; Barbosa et al., 2007; Baptista et al.,

2008; França and Araújo, 2007). Although there is little evidence of the decline of snake populations, there are reports of the decline of other reptiles as common black snake Pseudechis porphyriacus (Shaw, 1794) (Elapidae), however, these population declines may be difficult to detect long-term studies being regarded as indispensable for understanding normal population trends and fluctuations (Gibbons et al., 2000). Although there is no consensus among herpetologists about this aspect in relation to 
snakes, some believe they are disappearing throughout the world (Mullin and Seigel, 2009). The reason for this lack of consensus is the dearth of studies about snake populations (Reading et al., 2010).

Extinction is a natural process, but more than $98 \%$ of extinctions nowadays occur due to human activities (Raup and Stanley, 1978). Of the over 10,119 reptile species in the world, it is believed that at least 167 are endangered (Primack and Rodrigues, 2001; Dixo and Verdade, 2006; Uetz and Hošek, 2014). In Brazil there are 760 reptile species (Costa and Bérnils, 2014), five of which are on the country's list of endangered species and six of which are on the endangered list of the state of Minas Gerais (Martins and Molina, 2008).

Currently 3,496snake species are known, belonging to 22 families (Uetz and Hošek, 2014), forming the second largest group of reptiles in the world by number of species. In Brazil, 386 species have been recorded (Costa and Bérnils, 2014), of which only $15 \%$ are considered venomous (Elapidae and Viperidae families). However, some genera of the Dipsadidae family (=Colubridae), considered nonvenomous, are capable of causing bites. In Brazil, approximately $85 \%$ of snakebites are caused by species of the Bothrops (sensu stricto), a genus of venomous snakes (Ribeiro and Jorge, 1997; Costa-Neto, 2000; Salomão et al., 2003; Ribeiro et al., 2008).

To most people, snakes are only viewed as potentially dangerous and their trophic interactions with other animals are ignored (Lima-Verde, 1994). As a result, in various regions of Brazil snakes are negatively stereotyped as always being "dangerous animals". This attitude and other aspects of popular culture heighten the chance for conflicts between humans and snakes (Cardoso et al., 2003; Argôlo, 2004), by influencing the way people interact with these animals (Vizotto, 2003; Silva, 2006).

The purpose of this study was to evaluate the physical state of snakes deposited in the reptile collections of the Centro Universitário de Lavras - Unilavras and Universidade
Federal de Juiz de Fora - UFJF, both located in the state of Minas Gerais and relate the data obtained in the literature on the subject.

\section{Material and Methods}

This study was conducted between February 2008 and June 2013, examining specimens of snakes coming from both urban and rural areas in different localities of the Brazil, reptiles belonging to the collections of the University Center of Lavras laboratories - Unilavras and the Federal University Juiz de Fora. This snakes were recorded at different times in both collections. Injuries resulting from human capture of specimens donated to the two collections were observed under a stereoscopic microscope Bel Photonics ${ }^{\circledR}$.

The injuries were classified according to the location on the body: anterior portion (AP), from the head to the tenth ventral scale; middle portion (MP), from the tenth ventral scale to the cloacal plate; and posterior portion (PP), from the first scale after the cloaca until the end of the tail (PP). We decided to include the cephalic region in the anterior portion because in relation to the body size, the head is a too small a region to be considered separately. All information obtained about the injuries observed in dead snakes collected were rescued from the fall collections of books where the specimens were analyzed.

The relation between the place of injury and category of snake (venomous and nonvenomous) was analyzed by the Chi-square test, using Microsoft Excel 2007, at a 5\% level of significance.

\section{Results}

Among the 69 species and 449 specimens deposited and analyzed in the reptile collections of the two laboratories, 245 specimens of 52 species showed injury to one of the body portions (Table 1).

Table 1. Species of snake and number of specimens deposited and analyzed in the reptile collections of the Centro Universitário de Lavras - UNILAVRAS and Universidade Federal de Juiz de Fora - UFJF, and position of the injury.

\begin{tabular}{lcccc}
\hline \multicolumn{1}{c}{ Species } & $\begin{array}{c}\text { Total number in } \\
\text { the collections }\end{array}$ & $\begin{array}{c}\text { Total number and position of the } \\
\text { injury }\end{array}$ \\
\cline { 3 - 5 } & 4 & AP & MP & PP \\
\hline Apostolepis assimilis (Reinhardt, 1861) & 1 & 3 & 2 \\
Apostolepis sp. & 24 & 13 & 15 & 0 \\
Atractus pantostictus Fernandes \& Puorto, 1993 & 3 & 0 & 1 & 0 \\
Atractus torquatus (Duméril, Bibron \& Duméril, 1854) & 3 & 1 & 1 & 0 \\
Atractus zebrinus (Jan, 1862) & 18 & 6 & 4 & 0 \\
Bothrops alternatus Duméril, Bibron \& Duméril, 1854 & 2 & 1 & 0 & 0 \\
Bothrops atrox (Linnaeus, 1758) & 33 & 15 & 8 & 2 \\
Bothrops jararaca (Wied, 1824) & 1 & 0 & 0 & 0 \\
Bothrops moojeni Hoge, 1966 & 15 & 7 & 7 & 0 \\
Bothrops neuwiedi Wagler in Spix, 1824 & 2 & 1 & 0 & 0 \\
Bothrops sp. & 24 & 10 & 10 & 3 \\
Crotalus durissus cascavella Wagler in Spix, 1824 & & & 0 \\
\hline
\end{tabular}


Table 1. Continued...

\begin{tabular}{|c|c|c|c|c|}
\hline \multirow[t]{2}{*}{ Species } & \multirow{2}{*}{$\begin{array}{l}\text { Total number in } \\
\text { the collections }\end{array}$} & \multicolumn{3}{|c|}{$\begin{array}{l}\text { Total number and position of the } \\
\text { injury }\end{array}$} \\
\hline & & $\mathbf{A P}$ & MP & PP \\
\hline Chironius bicarinatus (Wied, 1820) & 5 & 1 & 1 & 1 \\
\hline Chironius exoletus (Linnaeus, 1758) & 1 & 1 & 0 & 0 \\
\hline Chironius flavolineatus (Jan, 1863) & 9 & 5 & 5 & 2 \\
\hline Chironius quadricarinatus (Boie, 1827) & 2 & 1 & 1 & 1 \\
\hline Chironius scurrulus (Wagler in Spix, 1824) & 1 & 0 & 0 & 0 \\
\hline Chironius sp. & 5 & 1 & 2 & 2 \\
\hline Dipsas catesbyi (Sentzen, 1796) & 2 & 0 & 0 & 0 \\
\hline Drepanoides anomalus (Jan, 1863) & 1 & 0 & 0 & 0 \\
\hline Drymoluber dichrous (Peters, 1863) & 1 & 0 & 0 & 0 \\
\hline Taeniophallus affinis (Günther, 1858) & 2 & 0 & 1 & 0 \\
\hline Echinanthera melanostigma (Wagler in Spix, 1824) & 3 & 0 & 0 & 0 \\
\hline Elapomorphus quinquelineatus (Raddi, 1820) & 12 & 8 & 7 & 3 \\
\hline Epicrates cenchria (Linnaeus, 1758) & 3 & 2 & 1 & 0 \\
\hline Erythrolamprus a. aesculapii (Linnaeus, 1766) & 7 & 1 & 2 & 0 \\
\hline Erythrolamprus almadensis (Wagler in Spix, 1824) & 1 & 0 & 0 & 0 \\
\hline Erythrolamprus m. miliaris (Linnaeus, 1758) & 11 & 4 & 5 & 1 \\
\hline Erythrolamprus p. poecilogyrus (Wied, 1825) & 9 & 2 & 2 & 1 \\
\hline Erythrolamprus sp. & 1 & 1 & 1 & 0 \\
\hline Erythrolamprus t. typhlus (Linnaeus, 1758) & 6 & 2 & 2 & 1 \\
\hline Leptodeira a. annulata (Linnaeus, 1758) & 6 & 4 & 4 & 1 \\
\hline Mastigodryas bifossatus (Raddi, 1820) & 2 & 2 & 1 & 1 \\
\hline Micrurus averyi Schmidt, 1939 & 2 & 0 & 0 & 0 \\
\hline Micrurus corallinus (Merrem, 1820) & 2 & 1 & 1 & 0 \\
\hline Micrurus decoratus (Jan, 1858) & 2 & 1 & 1 & 0 \\
\hline Micrurus frontalis (Duméril, Bibron \& Duméril, 1854) & 3 & 0 & 1 & 0 \\
\hline Micrurus h. hemprichii (Jan, 1858) & 2 & 1 & 0 & 0 \\
\hline Micrurus lemniscatus lemniscatus (Linnaeus, 1758) & 2 & 0 & 0 & 0 \\
\hline Micrurus s. spixii Wagler in Spix, 1824 & 2 & 1 & 1 & 0 \\
\hline Mussurana montana (Franco, Marques \& Puorto, 1997) & 4 & 1 & 1 & 0 \\
\hline Oxybelis aeneus (Wagler in Spix, 1824) & 2 & 1 & 2 & 1 \\
\hline Oxyrhopus clathratus Duméril, Bibron \& Duméril, 1854 & 15 & 4 & 5 & 1 \\
\hline Oxyrhopus guibei Hoge \& Romano, 1978 & 26 & 18 & 17 & 3 \\
\hline Oxyrhopus $m$. melanogenys Tschudi, 1845 & 1 & 0 & 0 & 0 \\
\hline Oxyrhopus petolarius digitalis (Reuss, 1834) & 3 & 0 & 1 & 0 \\
\hline Oxyrhopusr rhombifer Duméril, Bibron \& Duméril, 1854 & 3 & 0 & 0 & 0 \\
\hline Oxyrhopus sp. & 1 & 1 & 0 & 0 \\
\hline Oxyrhopus trigeminus Duméril, Bibron \& Duméril, 1854 & 3 & 1 & 1 & 0 \\
\hline Philodryas olfersii (Lichtenstein, 1823) & 9 & 4 & 5 & 1 \\
\hline Philodryas patagoniensis (Girard, 1858) & 7 & 2 & 2 & 1 \\
\hline Philodryas agassizii (Jan, 1863) & 1 & 0 & 1 & 0 \\
\hline Pseudoboa nigra (Duméril, Bibron \& Duméril, 1854) & 1 & 1 & 1 & 0 \\
\hline $\begin{array}{l}\text { Pseudoboa serrana Morato, Moura-Leite, Prudente \& } \\
\text { Bérnils, } 1995\end{array}$ & 2 & 1 & 0 & 0 \\
\hline Sibynomorphus m. mikanii (Schlegel, 1837) & 43 & 19 & 19 & 5 \\
\hline Sibynomorphus neuwiedi (Ihering, 1911) & 29 & 11 & 11 & 3 \\
\hline Sibynomorphus sp. & 1 & 0 & 0 & 0 \\
\hline Siphlophis cervinus (Laurenti, 1768) & 1 & 0 & 0 & 0 \\
\hline Spilotes p. pullatus (Linnaeus, 1758) & 1 & 1 & 0 & 0 \\
\hline Thamnodynastes hypoconia (Cope, 1860) & 2 & 0 & 0 & 0 \\
\hline Thamnodynastes sp. & 2 & 1 & 1 & 0 \\
\hline
\end{tabular}


Table 1. Continued...

\begin{tabular}{lcccc}
\hline \multirow{2}{*}{$\begin{array}{l}\text { Species } \\
\text { Thamnodynastes strigatus (Günther, 1858) }\end{array}$} & $\begin{array}{c}\text { Total number in } \\
\text { the collections }\end{array}$ & $\begin{array}{c}\text { Total number and position of the } \\
\text { injury }\end{array}$ \\
\cline { 3 - 5 } & & AP & MP & PP \\
\hline Tropidodryas striaticeps (Cope, 1869) & 3 & 4 & 1 & 0 \\
Xenodon merremii (Wagler in Spix, 1824) & 12 & 6 & 1 & 0 \\
Xenodon neuwiedii Günther, 1863 & 6 & 3 & 3 & 1 \\
Xenodon sp. & 1 & 1 & 0 & 0 \\
Xenopholis undulatus (Jensen, 1900) & 1 & 1 & 0 & 0 \\
Not identified & 28 & 12 & 12 & 7 \\
\hline
\end{tabular}

Table 2. Distribution of the injuries according to the position, number and danger level of the snakes.

\begin{tabular}{lcccc}
\hline \multicolumn{2}{c}{$\begin{array}{c}\text { Snake classification in relation to the } \\
\text { dentition }\end{array}$} & $\begin{array}{c}\text { Number of } \\
\text { specimens }\end{array}$ & AP & Position of the injury \\
\hline Venomous & 110 & 43 & 33 & PP \\
Solenoglyphs & 95 & 39 & 29 & 5 \\
Proteroglyphs & 15 & 4 & 4 & 5 \\
Nonvenomous & 311 & 88 & 89 & 0 \\
Aglyphs & 192 & 79 & 79 & 21 \\
Opisthoglyphs & 12 & 9 & 10 & 12 \\
\hline
\end{tabular}

Of all the specimens analyzed in both collections, nonvenomous snakes were in the majority, comprised on 311 specimens $(69.3 \%)$, while there were 110 venomous specimens $(24.4 \%)$ and 28 specimens $(6.3 \%)$ that could not be identified due to the severity of the injuries. However, the nonvenomous snakes had a higher percentage of injuries (66.3\%, absolute number), probably causing their death, in comparison with venomous snakes $(18.2 \%$, absolute number) (Table 2).

The majority of the nonvenomous snake specimens analyzed suffered injuries to the anterior portion (44.9\%), followed by the middle portion (43.9\%) and posterior portion (11.2\%). In turn, there were 44 specimens of venomous snakes with injuries, divided among the anterior portion $(53.6 \%)$, middle portion $(40.2 \%)$ and posterior portion $(6.2 \%)$. The body region with the greatest percentage of injuries was the anterior portion $(39.6 \%)$, followed by the middle $(36.5 \%)$ and posterior portion $(8.4 \%)$.

We did not find any statistical differences $(\mathrm{Q}=0.242$; $\mathrm{P}=2.835$ ) when analyzing the dependence of the body part with the category (venomous and nonvenomous).

\section{Discussion}

The data demonstrate that the injury rate of the nonvenomous snakes is much greater than that of the venomous ones. We believe this can be due to various specific characteristics of some species, such as mimetism and aposematic coloration, considered to be defense mechanisms, beyond consequences caused by fear, myths and popular beliefs.
From earliest history, snakes are considered objects for man curious fascination, as causing both fear and veneration (Lima-Verde, 1994). Many legends and superstitions are present in the minds of many people, since this group is part of the mythology of various peoples too (Pizzatto, 2003). The snake is regarded as an animal of evil in Christian culture (Genesis), in which "the snake represents temptation, being the smartest animal which God had created" (Pizzatto, 2003). Thus many legends and superstitions were created and passed from generation to generation, being counted and snakes seen as a threat or something bad that they can bring to people (see Bernarde, 2012). Another issue would be the lack of basic knowledge, since the practice of environmental education essential for conservation of this group would be (Bernarde, 2012). For example, snakes of the Elapidae family are morphologically very similar to species of the Oxyrophus genus (Dipsadidae family) (Sazima and Haddad, 1992; Marques et al., 2001). Therefore, peoples' inability to differentiate snakes leads to indiscriminate killing because of a belief they are dangerous, whether or not this is really the case. In general, the serpent that appears in various cultures both representing good and evil, is a symbol of strength and power, representing the mystery, the immortal, the unconscious.

According to Moura et al. (2010), in a study conducted in the state of Minas Gerais, $50 \%$ of respondents in a survey said they did not know to differentiate between poisonous and non-poisonous snakes. This paper also reports that people who took part in the study had a tendency to kill any snake species because they felt threatened. Another 
$50 \%$ of respondents said they could differentiate snakes from its default color, the shape of the head among other things. Many of these features can confuse most people, but are used by them, although they are typical features of European or African vipers, now widely disseminated to all Brazilian species.

Moura et al. (2010) analyzed two distinct populations. In one, $46 \%$ of respondents demonstrated a high level of hostility toward snakes, reporting that they were going to kill a snake if the opportunity arises, whereas in another population, less hostile, only $5 \%$ said that. The authors attributed this result to the level of education of participants and contact with science and environmental education activities. These results, together with data from this study demonstrate the importance of awareness and learning of both rural and urban on the interaction of human beings with all animal population. Silva (2006) reported that $65 \%$ of respondents from the rural municipality of Rio Branco in Acre staded said killed the snakes when they meet them. Only $12 \%$ of one population surveyed by Moura et al. (2010) stated that environmental police or call IBAMA (Brazilian environmental agency), while 14\% said they would allow the snakes to leave without harming them. Again the importance of ethnozoology snakes allied with studies of the practice of environmental education become important tools to have passed the information correctly and to people in general.

A large part of the population cannot differentiate between venomous and nonvenomous snakes because they lack sufficient knowledge or because they try to identify them erroneously, often only by means of coloration, head shape or tail size, among others. These characteristics lead to errors, a fact that can explain why the percentage of nonvenomous snakes was higher than that of venomous snakes.

Logic would dictate that the killing of snakes would decrease with greater awareness about them. Therefore, investigation of the knowledge of a determined community about the local fauna is important to define and orient environmental education campaigns aiming at preserving animal species. The investigation of traditional zoological knowledge, zootherapeutic practices and environmental education can allow greater clarification about snakes and reduce fear of them. Such efforts are necessary for better understanding and to propose strategies to preserve natural resources together with the human population of each region.

\section{Acknowledgements}

RV Gouveia was supported by a student fellowship from CAPES (Coordenação de Aperfeiçoamento de Pessoal de Nível Superior, Brazil). BM Sousa was supported by a Research fellowship from CNPq (Conselho Nacional de Pesquisa e Desenvolvimento Tecnológico, Brazil). IA Novelli was supported by a Postdoctoral fellowship from CAPES.

\section{References}

ARGÔLO, AJS., 2004. As serpentes dos cacauais do sudeste da Bahia. Bahia: Editus. 260 p.

BAPTISTA, GCS., COSTA-NETO, EM. and VALVERDE, MCC., 2008. Diálogo entre concepções prévias dos estudantes e conhecimento científico escolar: relações sobre os Amphisbaenia. Revista Iberoamericana de Educación, vol. 47, p. 1-16.

BARBOSA, AR., NISHIDA, AK., COSTA, ES. and CAZÉ, ALR., 2007. Abordagem etnoherpetológica de São José da Mata - Paraíba - Brasil. Revista de Biologia e Ciências da Terra, vol. 7, no. 2, p. 117-123.

BERNARDE, PS., 2012. Anfibios e répteis: introdução ao estudo da herpetofauna brasileira. Curitiba: Anolis Books. 320 p.

CARDOSO, JLC., FRANÇA, FOS., WEN, FH., MÁLAQUE, CMS. and HADDAD JUNIOR, V., 2003. Animais peçonhentos no Brasil: biologia, clínica e terapêutica dos acidentes. São Paulo: Sarvier. 468 p.

COSTA, HC. and BÉRNILS, RS., 2014. Répteis brasileiros: lista de espécies. Herpetologia Brasileira, vol. 3, no. 3, p. 7484. Available from: http://www.sbherpetologia.org.br/images/ LISTAS/2014.03-07-MudancasTaxonomicas.pdf. Access in: 26 Jun. 2015.

COSTA-NETO, EM., 2000. Conhecimento e usos tradicionais de recursos faunísticos por uma comunidade afro-brasileira resultados preliminares. Interciencia, vol. 25, no. 9, p. 423-431.

DIXO, M. and VERDADE, VK., 2006. Herpetofauna de serrapilheira da Reserva Florestal de Morro Grande, Cotia (SP). Biota Neotropica, vol. 6, no. 2, p. 1-20. http://dx.doi.org/10.1590/ S1676-06032006000200009.

FRANÇA, FGR. and ARAÚJO, AFB., 2007. Are there cooccurrence patterns that structure snake communities in Central Brazil? Brazilian Journal of Biology $=$ Revista Brasileira de Biologia, vol. 67, no. 1, p. 33-40. http://dx.doi.org/10.1590/ S1519-69842007000100005. PMid:17505747.

GIBBONS, JW., SCOTT, DE., RYAN, TJ., BUHLMANN, KA., TUBERVILLE, TD., METTS, BS., GREENE, JL., MILLS, T., LEIDEN, Y., POPPY, S. and WINNE, CT., 2000. The global decline of reptiles, déjà vu amphibians. Bioscience, vol. 50, no. 8, p. 653666. http://dx.doi.org/10.1641/0006-3568(2000)050[0653:TGD ORD]2.0.CO;2.

LIMA-VERDE, JS., 1994. Por que não matar as nossas cobras. In NASCIMENTO, LB. and OLIVEIRA, ME. (Eds). Herpetologia no Brasil I. Belo Horizonte: PUC/Biodiversitas. p. 92-101.

MARQUES, OAV., ETEROVIC, A. and SAZIMA, I., 2001. Serpentes da Mata Atlântica: guia ilustrado da serra do mar. São Paulo: Holos. 184 p.

MARTINS, M. and MOLINA, FB., 2008. Panorama geral dos répteis ameaçados do Brasil. In MACHADO, A., DRUMMOND, GM. and PAGLIA, AP. (Eds.). Livro vermelho da fauna brasileira ameaçada de extinção. Brasília: Ministério do Meio Ambiente; Belo Horizonte: Fundação Biodiversitas. p. 327-334.

MOURA, MR., COSTA, HC., SÃO-PEDRO, VA., FERNANDES, VD. and FEIO, RN., 2010. The relationship between people and snakes in Eastern Minas Gerais, Southeastern Brazil. Biota Neotropica, vol. 10, no. 4, p. 133-142.

MULLIN, SJ. and SEIGEL, RA., 2009. Snakes: ecology and conservation. New York: Cornell University Press. 384 p. 
POUGH, FH., ANDREWS, RM., CADLE, JE., CRUMP, ML., SAVITZKY, AH. and WELLS, KD., 2001. Herpetology. 2nd ed. New Jersey: Prentice Hall. 612 p.

PIZZATTO, L., 2003. O fascinante mundo das serpentes. Ciência Hoje, vol. 33, no. 197, p. 71-73.

PRIMACK, RB. and RODRIGUES, E., 2001. Biologia da conservação. Londrina: Editora Midiograf. 327 p.

RAUP, DM. and STANLEY, SM., 1978. Principles of paleontology. 2nd ed. San Francisco: W. H. Freeman and Company. 481 p.

READING, CJ., LUISELLI, LM., AKANI, GC., BONNET, X., AMORI, G., BALLOUARD, JM., FILIPPI, E., NAULLEAU, G., PEARSON, D. and RUGIERO, L., 2010. Are snake populations in widespread decline? Biology Letters, vol. 6, no. 6, p. 777-780. http://dx.doi.org/10.1098/rsbl.2010.0373. PMid:20534600.

RIBEIRO, LA. and JORGE, MT., 1997. Acidente por serpentes do gênero Bothrops: série de 3.139 casos. Revista da Sociedade Brasileira de Medicina Tropical, vol. 30, no. 6, p. 475-480. http:// dx.doi.org/10.1590/S0037-86821997000600006. PMid:9463193.

RIBEIRO, LA., GADIA, R. and JORGE, MT., 2008. Comparação entre a epidemiologia do acidente e a clínica do envenenamento por serpentes do gênero Bothrops, em adultos idosos e não idosos. Revista da Sociedade Brasileira de Medicina Tropical, vol. 41, no.
1, p. 46-49. http://dx.doi.org/10.1590/S0037-86822008000100009. PMid: 18368270

SALOMÃO, MG., ALBOLEA, ABP. and ALMEIDA-SANTOS, SM., 2003. Colubrid snakebite: a public health problem in Brazil. Herpetological Review, vol. 34, no. 3, p. 307-312.

SAZIMA, I. and HADDAD, CFB., 1992. Répteis da Serra do Japi: notas sobre história natural. In MORELLATO, PC. (Ed.). História natural da Serra do Japi: ecologia e preservação de uma área florestal no sudeste do Brasil. São Paulo: UNICAMP/ FAPESP. p. 212-236.

SILVA, MV., 2006. Serpentes do Estado do Acre: riqueza, dieta, etno-conhecimento e acidentes ofidicos. Rio Branco: Universidade Federal do Acre. 81 p. Doctoral thesis in Ecology and Natural Resource Management.

UETZ, P., and HOŠEK, J. (Eds.), 2014. The Reptile Database. Available from: $<$ http://www.reptile-database.org/>. Access in: 17 Jan. 2015.

VIZOTTO, LD., 2003. Serpentes: lendas, mitos, superstições e crendices. São Paulo: Plêidade. 240 p.

WILSON, EO., 1984. Status, conservation, and management. In DODD JUNIOR, CK. (Ed). Snakes ecology and evolution biology. New York: McGraw-Hill Publishing Company. p. 478-513. 